Vol. 4: 429-443.

\title{
Benefit of using plant growth regulators in fodder barley
}

\author{
Leila-Riitta Erviö and Heikki Jalli \\ Agricultural Research Centre of Finland, Institute of Plant Protection, \\ FIN-31600 Jokioinen, Finland \\ Markku Kontturi \\ Agricultural Research Centre of Finland, Institute of Crop and Soil Science \\ Heikki Hakkola \\ Agricultural Research Centre of Finland, North Finland Research Unit \\ Arjo Kangas \\ Agricultural Research Centre of Finland, West Finland Research Unit \\ Paavo Simojoki \\ Agricultural Research Centre of Finland, East Finland Research Unit
}

\begin{abstract}
The study was conducted to investigate the effect and benefit of applying plant growth regulators (PGR) to two easily lodging barley cultivars, Arra and Kilta, which were commonly used for fodder production all over Finland. Field trials were conducted at six experimental sites in different parts of the country. Of the PGRs tested, ethephon and mepiquat/ethephon were the most effective in shortening the culm and preventing lodging. However, neither could prevent the lodge adequately in all growing circumstances. When applied at flag-leaf stage (FS 10) they increased yield under conditions favourable for lodging. They also raised the volume weight of barley, which was important for the final price of the yield. The most important factors determining future lodging of barley were an effective temperature sum of over $+5^{\circ} \mathrm{C}$ and precipitation during the period from sowing to the beginning of tillering (FS 2). About $64-68 \%$ of the lodging risk of the cultivars studied could be predicted from weather conditions during early development of the crop. Local growing conditions and the presence of lodge had a marked impact on the results obtained with PGRs. In the case of moderate lodging the compound used determined whether a profit or loss was made on the crop. In the case of heavy lodging, compounds containing ethephon contributed to an economic return. Their application at flag-leaf stage gave a profit of FIM $70-390 \mathrm{ha}^{-1}$. Since the profitability of PGR treatments depended on lodging, treatments are recommended for fodder barley only when lodging is expected. The lodging risk can be predicted within certain limits at the tillering stage of barley.
\end{abstract}

Key words: profitability, ethephon, chlormequat, mepiquat, lodging, prognosis, weather factors, yield components, yield 


\section{AGRICULTURAL SCIENCE IN FINLAND}

\section{Erviö, L.-R. et al.: Benefit of using plant growth regulators in fodder barley}

\section{Introduction}

Treating growing cereals with plant growth regulators (PGR) is an established way of preventing lodging and of securing the yield. The range of compounds available for that purpose has increased during the last decade and they now provide good prospects for growth regulation at different developmental stages of the crop (Wünsche 1977, Woolley 1981, Karpenstein and Scheffer 1984). If the rates of growth substances in crop plants could be manipulated at a certain developmental phase, the yield formation could be regulated as desired at the same time (Brückner and Höfner 1980, Scheffer et al. 1983).

The PGRs available for cereal crops in Finland are chlormequat chloride (CCC, several products), and ethephon both as such ('Cerone') and in a mixture with mepiquat ('Terpal'). CCC has not been satisfactory in preventing lodging of six-row barley under Finnish conditions. When compounds containing ethephon first came on the market, they were expected to be effective in preventing lodging of barley. The need was great, especially for six-row fodder barley in central and northern Finland, where early cultivars, which always have a tendency to lodging, are important. Lodging is further promoted in these areas by the growing conditions, in particular by the high light intensity and high soil moisture content.

Synergistic effects of growth regulators in mixtures have been reported in some studies (Scheffer et al. 1983, Jung et al. 1987). Simultaneous use of two or more PGRs has reinforced their reducing effect on culm length (Höfner and Kühn 1982), promoted shoot survival (Scheffer et al. 1983) and significantly increased ears $\mathrm{m}^{-2}$ (Ma and Smith 1991). CCC has usually been one component in the mixtures. By exploiting the synergistic effects of PGRs in mixtures one might be able to cut costs in practical farming, as the effect of a cheaper compound could be enhanced by adding a small amount of a more effective, but more expensive, product.
From the economic point of view, the treatments should be cost effective for the production of fodder. Many studies have shown that the profitability of using PGRs on barley depends on the presence of lodging (Woolley 1981, Herbert 1983, Moes 1990). Since PGRs have to be applied between the shooting and flag-leaf stages of barley, it is important to be able to asses the probability of future lodging and the need for PGR treatments.

The objectives of this study were to develop a method for predicting lodging at early stages of barley growth, to examine the effect of PGRs on preventing lodging, and on yield and yield components of early spring barley cultivars in different environments. The profitability of using PGRs in fodder barley production was also evaluated.

Some tank mixtures of ethephon and chlormequat were also studied to establish the beneficial synergistic effects of PGRs in regulating the lodge resistance of culms and the development of yield components.

\section{Material and methods}

\section{Field trials}

The study was conducted by the Institute of Plant Protection (KSL) of the Agricultural Research Centre located at Jokioinen in southern Finland. In addition five research stations took part in the investigation. They were Satakunta (SAT) in southern Finland, Laukaa (LAU) and South Ostrobothnia (EPO) in central Finland and Toholampi (TKP) and North Ostrobothnia (PPO) in northern Finland.

Since growing conditions varied from one site to another, data on soil and nutrition properties in the field trials and on weather conditions at the experimental locations are presented in Tables 1 and 3.

Six to ten PGR treatments as listed in Table 2 were studied in field trials at each experimen- 
Vol. 4: 429-443.

tal site. The plot size was $30 \mathrm{~m}^{2}$ at Jokioinen (KSL) and $20 \mathrm{~m}^{2}$ at the other sites. Each treatment was accomplished with four replicates.

In 1985-87 the trials were arranged in a randomized block design with one nitrogen level determined as typical of local farming practice (Table 1). In 1988-89, two levels of nitrogen fertilization were included in the trial programme. The higher level $\left(\mathrm{N}_{2}\right)$ was typical of local farming practice and the lower level $\left(\mathrm{N}_{1}\right)$ was half of that (Table 1). The trials were laid out in a splitsplit-plot design using cultivars as the main plots and nitrogen levels as the sub-plots. The six-row spring barley cultivars Arra and Kilta were chosen as the targets of study because of their tendency to lodging and widespread use for fodder production troughout Finland. The seeding rate was 500 kernels $\mathrm{m}^{-2}$. The seeds were treated with fungicides against plant diseases.

\section{PGR treatments}

The active ingredients ha ${ }^{-1}$ and timing of the PGR treatments are listed in Table 2. The compounds were applied with a gas-powered "van der Weij"- type sprayer, provided with a wind shield and flat nozzles. The water volume was $200 \mathrm{l} \mathrm{ha}^{-1}$ and spraying pressure $300 \mathrm{kPA}$.

The study was started before ethephon-containing compounds were approved for marketing in Finland. The doses of ethephon and CCC used in the first year proved to be unnecessarily high and were lowered in succeeding years (Table 2). The studied doses of ethephon and mepiquat/ethephon correspond to the highest rates currently recommended for easily lodging barley cultivars.

\section{Assessments and yield components}

After the crop had emerged, a sample area of one row metre was marked on each plot. Emerged barley plants in these areas were counted and collected before harvest for yield component analyses. The number and weight of culms and ears, the number and weight of grains per ear, the proportion of green grains in the yield and the harvest index $(\mathrm{HI})$ were determined for the samples. HI is the ratio of grain yield to total dry matter above ground.

Table 1. Data on field trials at different locations in 1985-89. Locations: KSL = Institute of Plant Protection and experimental stations SAT $=$ Satakunta, $\mathrm{LAU}=$ Laukaa, EPO $=$ South Ostrobothnia, $\mathrm{TKP}=\mathrm{Toho-}$ lampi, PPO = North Ostrobothnia.

\begin{tabular}{lrrrrrr}
\hline & KSL & SAT & LAU & EPO & TKP & PPO \\
\hline $\begin{array}{l}\text { Number of trials on } \\
\text { different soil types: }\end{array}$ & & & & & & \\
- coarse mineral soil & 0 & 14 & 10 & 8 & 8 & 5 \\
- clay & 14 & 0 & 1 & 6 & 0 & 0 \\
- organic & 0 & 0 & 0 & 0 & 4 & 2 \\
pH $\left(\mathrm{H}_{2} \mathrm{O}\right)$ & $5.8-6.3$ & $5.9-6.2$ & $5.1-6.1$ & $5.4-6.7$ & $5.4-5.9$ & $5.4-6.5$ \\
Fertilization $\mathrm{kg} \mathrm{ha}^{-1}$ & & & & & & \\
$-\mathrm{N}_{1}{ }^{1}$ & 60 & 50 & 53 & $60-80$ & $50-64$ & $50-58$ \\
$-\mathrm{N}_{2}{ }^{1)}$ & 120 & 100 & $96-100$ & 120 & $100-128$ & $100-117$ \\
$-\mathrm{P}^{2}{ }^{2}$ & $12-24$ & $50-54$ & $23-53$ & $23-35$ & $23-80$ & $18-44$ \\
$-\mathrm{K}$ & $24-48$ & $102-133$ & $44-100$ & $45-65$ & $45-144$ & $35-81$ \\
\hline
\end{tabular}

\footnotetext{
1) $\mathrm{N}_{1}$ in $1988-89$

$\mathrm{N}_{2}$ in $1985-87$ and $1988-89$

2) According to soil type
} 
Erviö, L.-R. et al.: Benefit of using plant growth regulators in fodder barley

Table 2. Treatments of plant growth regulators in barley 1985- 89. Time I=beginning of tillering (FS 2), II=1-node stage (FS 6), III=flag-leaf stage (FS 10) (Large 1954).

\begin{tabular}{|c|c|c|c|c|}
\hline Treatments & $\begin{array}{c}\text { Dose a.i } \\
1 \mathrm{ha}^{-1}\end{array}$ & & $\begin{array}{l}\text { Treatment time } \\
\text { Feekes Scale }\end{array}$ & $\begin{array}{c}\text { Nitrogen } \\
\text { level }\end{array}$ \\
\hline & 1985 & $1986-87$ & & \\
\hline 1. Untreated & & - & - & N2 \\
\hline 2. $\mathrm{CCC}$ & 0.4 & 0.2 & I FS 2 & N2 \\
\hline 3. $\mathrm{CCC}$ & 1.5 & 0.5 & II FS 6 & $\mathrm{~N} 2$ \\
\hline 4. CCC+mepiquat & $1.5+0.4$ & $0.5+0.1$ & II FS 6 & N2 \\
\hline 5. CCC+ethephon & $1.5+0.3$ & $0.5+0.1$ & II FS 6 & N2 \\
\hline 6. ethephon & 0.7 & 0.35 & II FS 6 & N2 \\
\hline 7. mepiquat/ethephon & $0.46 / 0.23$ & $0.46 / 0.23$ & II FS 6 & $\mathrm{~N} 2$ \\
\hline 8. CCC+ethephon & $1.5+0.3$ & $0.5+0.1$ & III FS 10 & $\mathrm{~N} 2$ \\
\hline 9. ethephon & 0.7 & 0.35 & III FS 10 & N2 \\
\hline \multirow[t]{2}{*}{ 10. mepiquat/ethephon } & $0.46 / 0.23$ & $0.46 / 0.23$ & III FS 10 & $\mathrm{~N} 2$ \\
\hline & & $1988-89$ & & \\
\hline 1. Untreated & & - & - & $\mathrm{N} 1, \mathrm{~N} 2$ \\
\hline 2. $\mathrm{CCC}$ & & 0.2 & I FS 2 & $\mathrm{~N} 1, \mathrm{~N} 2$ \\
\hline 3. CCC & & 0.5 & II FS 6 & $\mathrm{~N} 1, \mathrm{~N} 2$ \\
\hline 7. mepiquat/ethephon & & $0.46 / 0.23$ & II FS 6 & $\mathrm{~N} 1, \mathrm{~N} 2$ \\
\hline 9. ethephon & & 0.35 & III FS 10 & $\mathrm{~N} 1, \mathrm{~N} 2$ \\
\hline 10. mepiquat/ethephon & & $0.46 / 0.23$ & III FS 10 & $\mathrm{~N} 1, \mathrm{~N} 2$ \\
\hline
\end{tabular}

Water volume $200 \mathrm{l} / \mathrm{ha}$.

The height of the stand was measured at the stage defined as milky rape 11.1 on the Feekes scale (FS) (Large 1954) at five places per plot. The height representing the majority of the culms in the stand was measured from the soil surface to the awn tops. The first date of lodging was recorded. Immediately before harvest, lodging was visually assessed on a scale of $0-100 \%$ $(0=$ no lodge, $100=$ completely lodged $)$, taking into account the angle of culms and the lodged area of each plot.

The crops were harvested with a combine, when ripe for cutting (FS 11.4), and the grain yield per plot was weighed. Volume weight $(\mathrm{kg}$ $\mathrm{hl}^{-1}$ ), grain moisture at harvest, kernel weight $(\mathrm{mg})$ and grain protein concentration (\%) were determined on the harvested yield with standard methods to establish the price of the grain yield.

No plant diseases were observed. Weed control was applied if necessary.

\section{Predicting lodging}

To establish which factors predict future lodging of barley, the data on mean temperature, effective temperature sum (ETS) over $0^{\circ},+2^{\circ}$ and $+5^{\circ} \mathrm{C}$ and precipitation (PR) recorded at different time intervals during the growing period of barley were studied in relation to lodging by regression analysis. Statistically significant $(\mathrm{P}=0.15)$ variables were included in the regression equation one by one and the equation was recalculated until no more significant variables remained.

\section{Profitability of treatments}

The economic return on PGR treatments was measured by the monetary profit obtained from the yield at the price level of spring 1992. The 


\section{AGRICULTURAL SCIENCE IN FINLAND}

Vol. 4: 429-443.

calculation was based on a yield with $15 \%$ moisture content using the price of fodder barley, FIM $1.82 \mathrm{~kg}^{-1}$, minus a marketing cost of FIM 0.30 . The yield price was corrected if necessary, according to the volume weight. The cost of spraying with hired equipment FIM $50 \mathrm{ha}^{-1}$ (Työtehoseuran maataloustiedote 1992) and the price of PGRs depending on the compound, were deducted from the yield profit. Because of the step-up scale used for the market prices of PGRs, the cost of treatments fluctuated considerably during the year. Here the following costs per ha were applied: CCC $0.21 \mathrm{ha}^{-1}$ FIM 29, CCC $0.51 \mathrm{ha}^{-1}$ FIM 81, CCC+mepiquat FIM 227, CCC+ethephon FIM 129, ethephon FIM 169 and mepiquat/ ethephon FIM 201. The nitrogen level $\mathrm{N}_{1}$ cost was FIM 82 and that of $\mathrm{N}_{2}$ FIM $155 \mathrm{ha}^{-1}$. The price of the yield corresponding to $100 \mathrm{~kg} \mathrm{ha}^{-1}$ as trampling losses (Köylijärvi 1985) was deducted from the profit of flag-leaf stage treatments.

\section{Statistical analyses}

The material showed that the lodging rate in untreated plots of different trials varied widely without any clear connection with the year or the geographical location of the experimental site. To eliminate this kind of variation the data obtained in 1985-87 were classified according to the rate of lodging in untreated plots into the following three groups:

$$
\begin{array}{ll}
1=\text { lodging } & 0-25 \% \\
2= & \quad 26-70 \% \\
3= & \quad 71-100 \%
\end{array}
$$

The majority of the trials in 1987 were assigned to class 3 , whereas some trials in other years fell in all classes.

Owing to the small size of the data set for 198889 , it could not be classified in the same way.

The effects of PGR treatments, nitrogen levels and cultivars and their interactions were established by analysis of variance. The significance of the differences between the means was tested by Tukey's test (HSD, P=0.05).

\section{Weather conditions in growing seasons 1985-89}

Weather conditions varied considerably between sites and years (Table 3). The most unfavourable year was 1987, which as a whole, was cold and rainy. Early May 1985 was rather cool and night frosts occurred. Growing seasons 1986 and 1988 began early and warm weather favoured plant developement.

In 1989, the weather was cool at the beginning of plant growth. Later on, the growing season turned warmer and, as a whole, was favourable to the growth of crops.

Showers were typical of the whole study period causing considerable variation in precipitation between the experimental sites. Thus the stands suffered drought or excessive wetting, depending on the location of the trial.

\section{Results}

\section{Factors affecting lodging}

The main growing factors affecting lodging were effective temperature sum (ETS) over $5^{\circ} \mathrm{C}$ and precipitation (PR, $\mathrm{mm}$ ) during the time between sowing and beginning of tillering (FS 2). Weather conditions during this time explained 64\% (P > 0.0001 ) of the lodging of Arra according to the equation: Lodging $=992.716-10.510 \times$ ETS + $0.028(\text { ETS })^{2}+0.008(\mathrm{PR})^{2} .68 \%(\mathrm{P}>0.0002)$ of the lodging of Kilta was explained by the equation: Lodging $=1071.853-11.567 \times$ ETS + $0.031(\text { ETS })^{2}+0.010(\mathrm{PR})^{2}$.

Thus, $64-68 \%$ of the risk of lodging can be predicted by weather conditions during the period in question. The weather factors of other growing season intervals included in the model did not raise its explanatory level. However, local showers in late summer increased the lodging of barley and gave a rising trend to the figures (Fig. 1). The highest values for weather factors in the figures are calculatory; being extra- 
Erviö, L.-R. et al.: Benefit of using plant growth regulators in fodder barley

Table 3. Effective temperature sum (ETS, base $+5^{\circ} \mathrm{C}$ ), cumulative precipitation (PR, $\mathrm{mm}$ ) and prognosis for lodging of cv. Arra and Kilta in the 1985-89 growing seasons at different locations. The lower $\mathrm{N}$ level is omitted. 1 = time interval between sowing date and first PGR treatment of the crop, $2=$ interval from beginning of growing season to 1 September, when $70 \%$ of the trials were harvested. $+=$ risk based on ETS or PR, ++ = risk based on combination of ETS and PR, $-=$ no risk. Locations: KSL = Institute of Plant Protection and experimental stations SAT $=$ Satakunta, $\mathrm{LAU}=\mathrm{Laukaa}, \mathrm{EPO}=$ South Ostrobothnia, $\mathrm{TKP}=$ Toholampi, PPO = North Ostrobothnia.

\begin{tabular}{|c|c|c|c|c|c|c|c|}
\hline \multicolumn{2}{|c|}{ Site and year } & \multicolumn{2}{|c|}{$\mathrm{ETS}^{\circ} \mathrm{C} / \mathrm{PR} \mathrm{mm}$} & \multicolumn{2}{|c|}{ Prognosis of lodging } & \multicolumn{2}{|c|}{ Occurred lodging $\%$} \\
\hline & & 1 & 2 & Arra & Kilta & Arra & Kilta \\
\hline \multirow[t]{5}{*}{ KSL } & 1985 & $162 / 45$ & $1027 / 238$ & ++ & ++ & 0 & 0 \\
\hline & 1986 & $173 / 40$ & $1138 / 244$ & ++ & - & 0 & 0 \\
\hline & 1987 & $160 / 73$ & $831 / 269$ & ++ & ++ & 69 & 47 \\
\hline & 1988 & $217 / 27$ & $1268 / 275$ & ++ & + & 8 & 0 \\
\hline & 1989 & $162 / 30$ & $1146 / 277$ & ++ & + & 56 & 0 \\
\hline \multirow[t]{5}{*}{ SAT } & 1985 & $138 / 30$ & $1037 / 202$ & ++ & + & 91 & 89 \\
\hline & 1986 & $142 / 12$ & $1128 / 195$ & + & + & 55 & 46 \\
\hline & 1987 & $136 / 74$ & $824 / 320$ & ++ & ++ & 97 & 96 \\
\hline & 1988 & $157 / 83$ & $1238 / 320$ & ++ & ++ & 45 & 71 \\
\hline & 1989 & $176 / 83$ & $1153 / 257$ & + & + & 65 & 85 \\
\hline \multirow[t]{5}{*}{ LAU } & 1985 & $196 / 45$ & $987 / 266$ & + & - & 0 & 0 \\
\hline & 1986 & $213 / 43$ & $1074 / 311$ & ++ & 1) & 25 & 1) \\
\hline & 1987 & $180 / 96$ & $775 / 371$ & + & 1) & 79 & 1) \\
\hline & 1988 & $186 / 55$ & $1162 / 338$ & + & + & 0 & 0 \\
\hline & 1989 & $197 / 56$ & $1098 / 307$ & + & + & 58 & 11 \\
\hline \multirow[t]{5}{*}{ EPO } & 1985 & 190/51 & $982 / 189$ & + & + & 26 & 0 \\
\hline & 1986 & $169 / 34$ & $1066 / 242$ & ++ & - & 6 & 15 \\
\hline & 1987 & $141 / 58$ & $766 / 166$ & ++ & ++ & 90 & 93 \\
\hline & 1988 & $174 / 60$ & $1168 / 297$ & ++ & + & 62 & 75 \\
\hline & 1989 & $183 / 76$ & $1116 / 274$ & + & + & 34 & 45 \\
\hline \multirow[t]{5}{*}{ TKP } & 1985 & $181 / 39$ & $931 / 231$ & + & - & 22 & 2 \\
\hline & 1986 & $235 / 11$ & $1030 / 259$ & + & + & 71 & 69 \\
\hline & 1987 & 1) & $770 / 306$ & 1) & 1) & 1) & 1) \\
\hline & 1988 & $144 / 37$ & $1103 / 347$ & + & + & 23 & 14 \\
\hline & 1989 & $156 / 82$ & $1042 / 492$ & ++ & + & 88 & 65 \\
\hline \multirow[t]{5}{*}{ PPO } & 1985 & $172 / 31$ & $886 / 228$ & ++ & 1) & 31 & 1) \\
\hline & 1986 & $178 / 71$ & $956 / 275$ & + & 1) & 65 & 1) \\
\hline & 1987 & $158 / 66$ & $728 / 305$ & ++ & 1) & 94 & 1) \\
\hline & 1988 & $133 / 19$ & $1072 / 223$ & + & 1) & 56 & 1) \\
\hline & 1989 & $160 / 84$ & $1000 / 324$ & ++ & 1) & 66 & 1) \\
\hline
\end{tabular}

1) No trial

polated from the equations they cannot be considered realistic.

According to the model, the risk of lodging in Kilta was generally lowest $(0-5 \%)$ when the ETS was $165^{\circ}-215^{\circ} \mathrm{C}$ and precipitation below $45 \mathrm{~mm}$. Arra has a persistent tendency to lodging. The lowest rates of lodge $(0-5 \%)$ can be ex- pected between ETS $175^{\circ}$ and $200^{\circ} \mathrm{C}$ when the precipitation is below $25 \mathrm{~mm}$.

The combination of ETS and PR during the risky period (Table 3) indicated a risk of lodge for either cultivar every year at KSL, and in 1987 at SAT, EPO and PPO; 1988 was risky at SAT and EPO, and 1989 at TKP and PPO. On the basis 
Vol. 4: 429-443.

a)

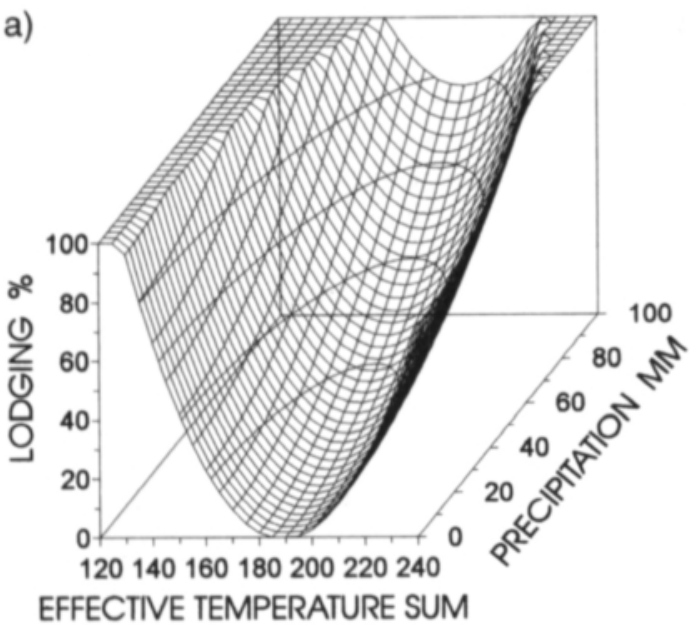

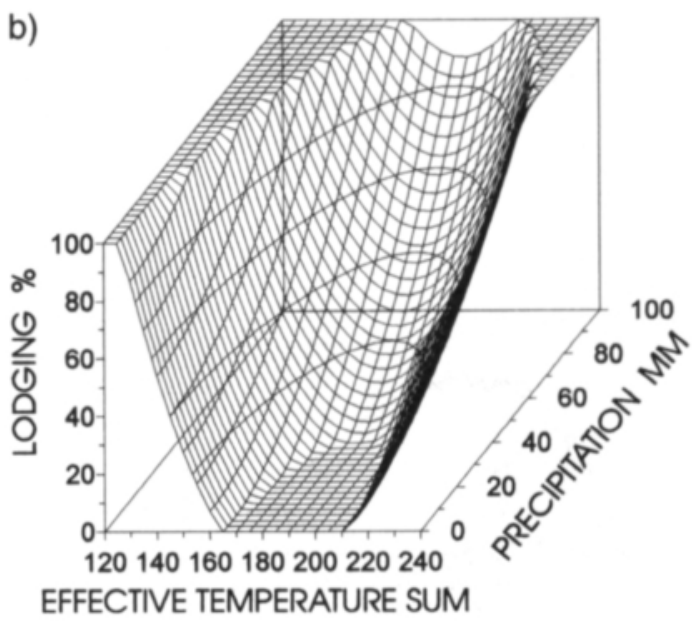

b)

EFFECTIVE TEMPERATURE SUM

Fig. 1. Lodging prognosis for cvs. a) Arra and b) Kilta based on the effective temperature sum and precipitation between sowing date and beginning of tillering (FS 2) of barley.

of temperature or precipitation lodging could be expected in several years at different locations. Most of the observed occurrences of lodging matched the prognosis; only 11 out of 51 assessments (i.e. $22 \%$ ) failed.

\section{Effect of variety and treatments}

In terms of lodging and yield properties the interactions between cultivars and treatments were not significant. Kilta had a higher kernel weight and harvest index than Arra; it also produced a higher yield and had more grains per ear than Arra. However, within cultivars each PGR treatment had a similar effect on these properties. In consequence, the data on the effect of treatments were pooled across the cultivars separately for 1985-87 and 1988-89.

\section{Height and lodging}

The treatments with mepiquat/ethephon and ethephon alone or in mixtures decreased culm height in all classes from 5 to $14 \mathrm{~cm}$ in 1985-87 (Fig. 2). Applications at flag-leaf stage were most effective. The effect of CCC on culm length was not significant.

Considerable lodging ( $>25 \%)$ occurred in $62 \%$ of all trials, and $26 \%$ of the cases were severely $(>70 \%)$ lodged. On the basis of classification $1-3$, lodging was most severe in the third group in 1985-87. The late applications of mepiquat/ethephon and ethephon, which significantly shortened the culm height were the most effective in preventing lodge. However, not even they could prevent lodge adequately in the worst cases.

At different $\mathrm{N}$ levels, all applications except the earliest CCC treatment shortened barley in 1988-89 (Fig. 3). Lodging was prevented most effectively with late applications of mepiquat/ ethephon, ethephon and the $\mathrm{CCC}+$ ethephon mixture at both nitrogen levels.

\section{Grain yield, weight and protein concentration}

In 1985-87 significant differences between treatments in the yield of barley were observed only in class 3 , in which the latest applications of mepiquat/ethephon and ethephon increased the yield by 350 and $480 \mathrm{~kg} \mathrm{ha}^{-1}$, respectively (Fig. 4). 


\section{AGRICULTURAL SCIENCE IN FINLAND}

Erviö, L.-R. et al.: Benefit of using plant growth regulators in fodder barley
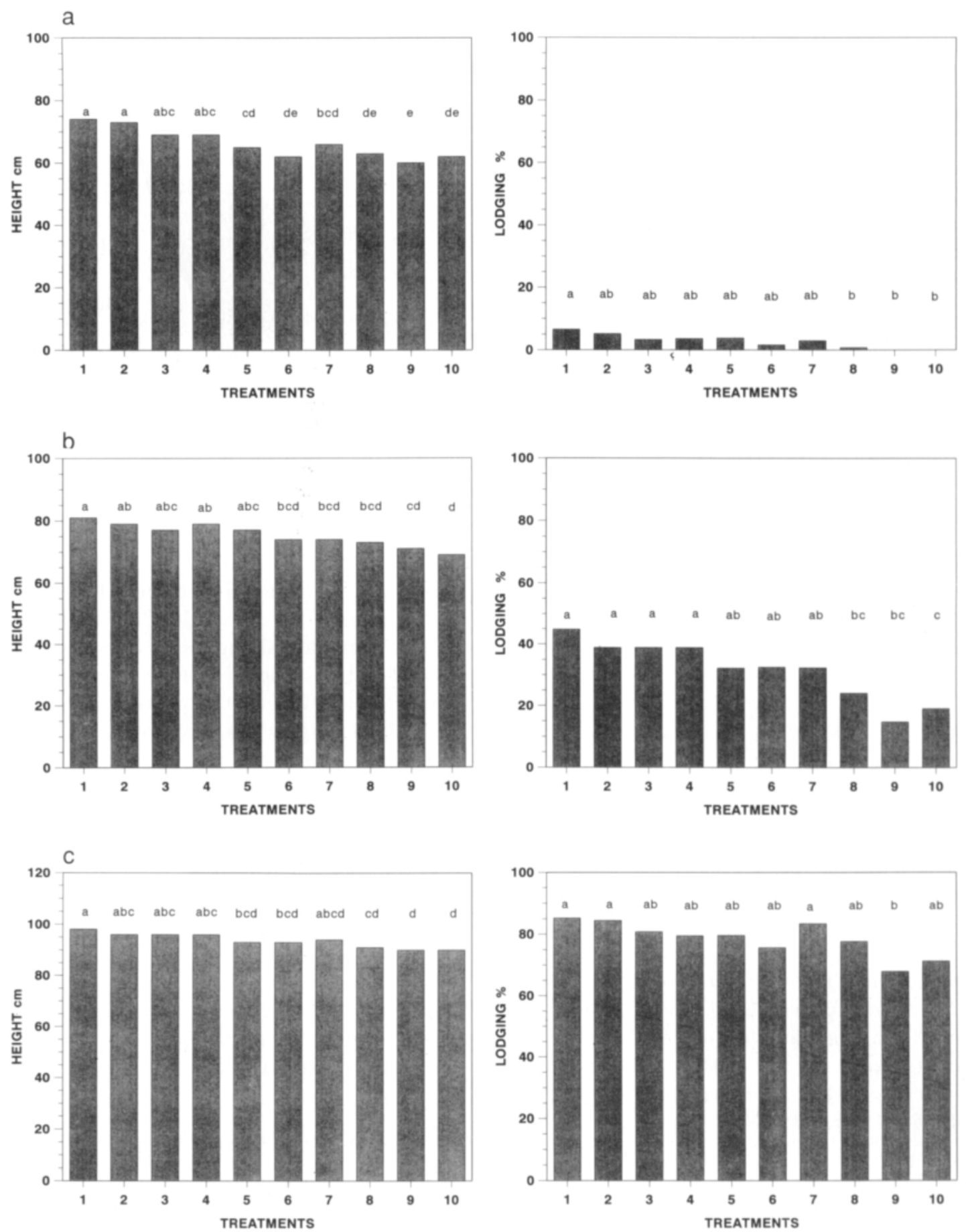

Fig 2. Effect of PGR treatments on height and lodging of barley in 1985-87. a) class 1, b) class 2, c) class 3. Means of treatments followed by the same superscript letter in each class are not significantly different at level $\mathrm{P}=0.05$.

Treatments: 1 = untreated, 2 = CCC, time I, 3 = CCC II, 4 = CCC+mepiquat II, 5 = CCC+ethephon II, 6 = ethephon II, $7=$ mepiquat/ethephon II, 8 = CCC+ethephon III, $9=$ ethephon III, $10=$ mepiquat/ethephon III. 


\section{AGRICULTURAL SCIENCE IN FINLAND}

Vol. 4: 429-443.
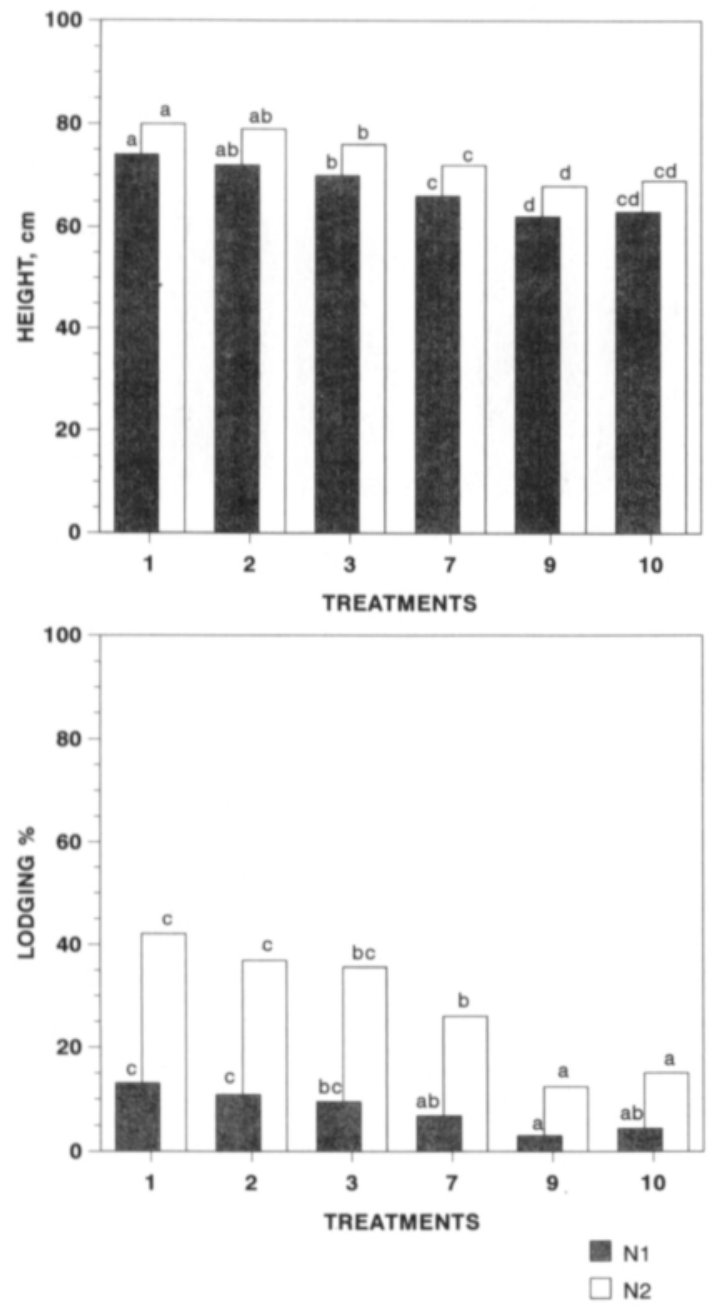

Fig. 3. Effect of PGR treatments on height and lodging of barley at different $\mathrm{N}$ levels in 1988-89. Means of treatments followed by the same superscript letter at each $\mathrm{N}$ level are not significantly different at level $\mathrm{P}=0.05$.

Treatments: 1 = untreated, 2 = CCC time I, $3=$ CCC II, 7 = mepiquat/ethephon II, 9 = ethephon III, 10 = mepiquat/ ethephon III.

Grain volume weight and kernel weight were influenced by the treatments in different ways, depending on the lodging classification (Fig. 5). In the event of severe lodging (class 3), late treatments with ethephon compounds increased the volume weight, which was important for the price of the yield.

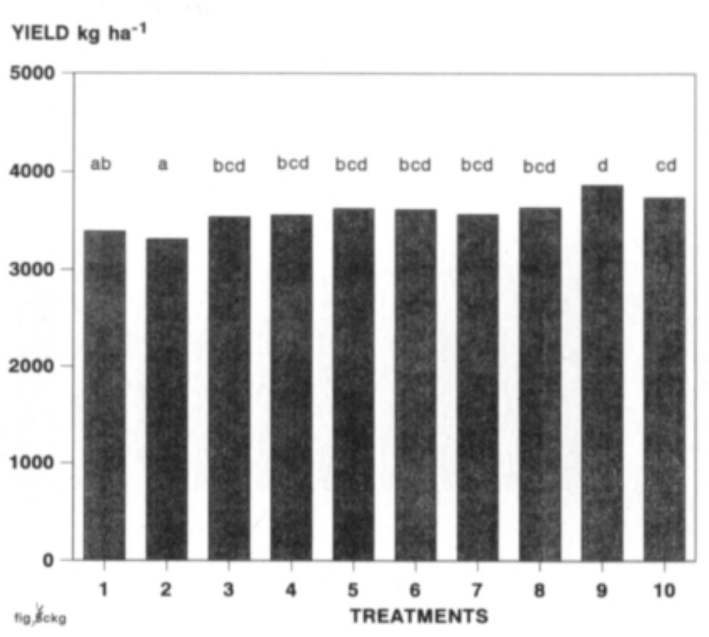

Fig. 4. Effect of PGR treatments on yield of barley in class 3 in 1985-87. Means of treatments followed by the same superscript letter are not significantly different at level $\mathrm{P}=$ 0.05 .

Treatments: $1=$ untreated, $2=$ CCC, time I, $3=$ CCC II, 4 = CCC+mepiquat II, $5=\mathrm{CCC}+$ ethephon II, $6=$ ethephon II, 7 = mepiquat/ethephon II, 8 = CCC+ethephon III, 9 = ethephon III, 10=mepiquat/ethephon III.

The average grain protein concentration was $14.8 \%$. Only early application of ethephon lowered it significantly in classes $1(14.2 \%)$ and 3 (13.4\%).

Treatments did not affect the yield of barley at either nitrogen level in 1988-89. Compared with untreated plots early mepiquat/ethephon application decreased the volume weight, the kernel weight, and the grain protein concentration at both nitrogen levels (data not given).

\section{Yield components and grain moisture}

In 1985-87, late application of ethephon decreased the weight of ears in class 1 . In class 3 , treatments usually raised the $\mathrm{HI}$ and grain number per ear (data not given). The treatments had no effect on the other yield components measured or on the proportion of green grains. 


\section{AGRICULTURAL SCIENCE IN FINLAND}

Erviö, L.-R. et al.: Benefit of using plant growth regulators in fodder barley
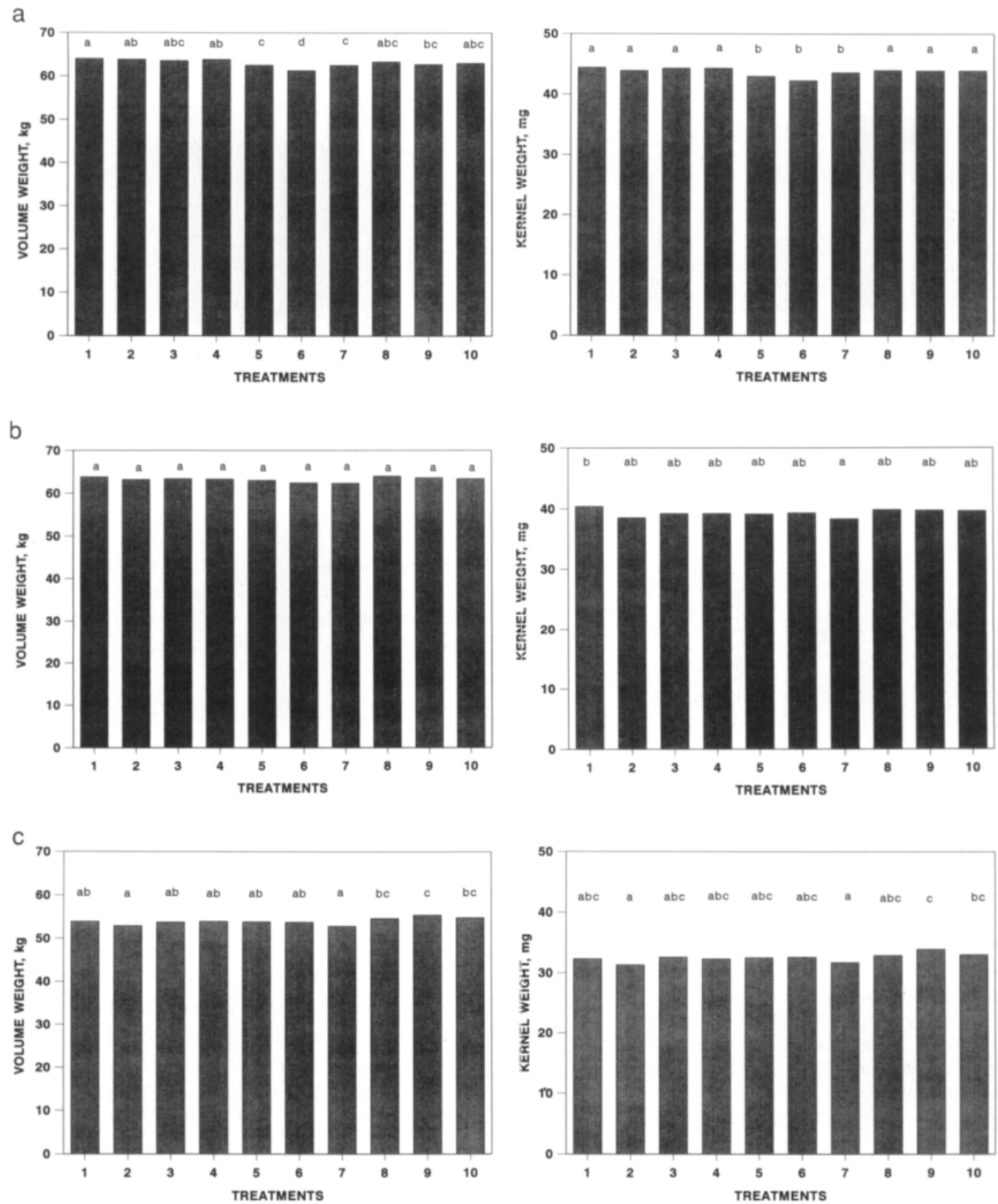

Fig. 5. Effect of PGR treatments on volume weight and kernel weight of barley in 1985-87. a) class 1, b) class 2, c) class 3 . Means of treatments followed by the same superscript letter in each class are not significantly different at level $\mathrm{P}=0.05$. Treatments: 1 = untreated, 2 = CCC, time I, $3=$ CCC II, $4=$ CCC+mepiquat II, $5=$ CCC +ethephon II, $6=$ ethephon II, 7 = mepiquat/ethephon II, 8 = CCC+ethephon III, $9=$ ethephon III, $10=$ mepiquat/ethephon III. 
Vol. 4: 429-443.
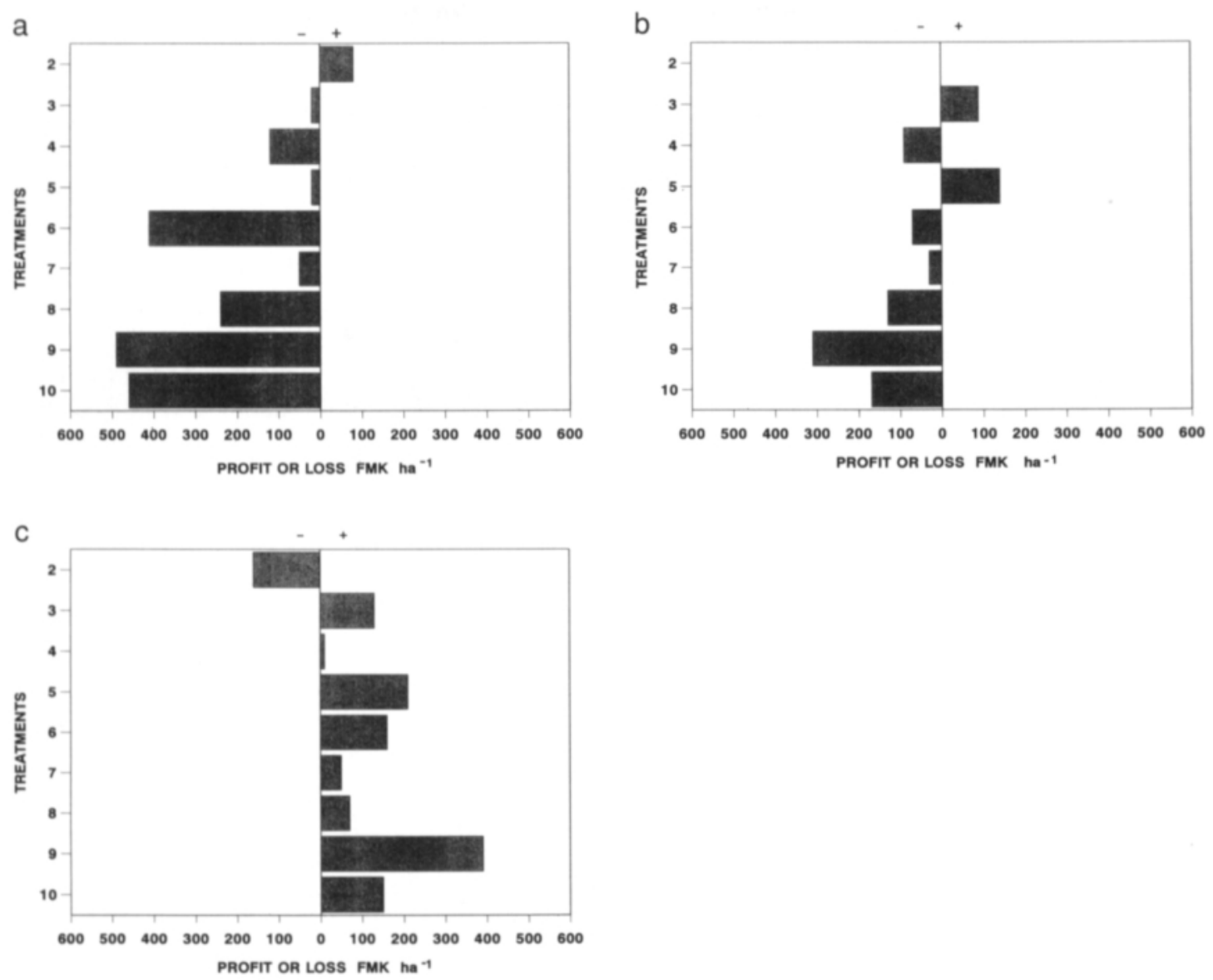

Fig. 6. Profitability of PGR treatments in different classes in 1985-87. a) class 1, comprises 11 trials, b) class 2, 6 trials, c) class 3, 11 trials.

Treatments: 1 = untreated, 2 = CCC, time I, 3 = CCC II, $4=$ CCC+mepiquat II, $5=$ CCC+ethephon II, $6=$ ethephon II, 7 = mepiquat/ethephon II, 8 = CCC + ethephon III, $9=$ ethephon III, $10=$ mepiquat/ethephon III.

Grain moisture varied from one class to another, usually being lowest in group 1 and highest in group 3 (data not shown). Significant moisture differences between treatments could not be reliably tested because of the low number of observations in each group. According to the field assesments ethephon delayed the ripening of barley by about one day.

In 1988-89, small differences between treatments occurred in the number of ear-bearing culms, grains per ear and $\mathrm{HI}$ but they were not significant when compared with untreated plants at either nitrogen level (data not given).

\section{Profitability of treatments}

The use of PGRs was not profitable under the conditions existing in class 1 (Fig. 6). Only the early application of chlormequat gave a favourable result.

In class 2, with variable lodging, the PGR treatments resulted in a profit or loss depending on the compound used. The best result was achieved with a mixture of $\mathrm{CCC}+$ ethephon applied at the 1-node stage (FS 6). Treatment with ethephon at the flag-leaf stage (FS 10) was the least profitable. 
Erviö, L. $-R$. et al.: Benefit of using plant growth regulators in fodder barley

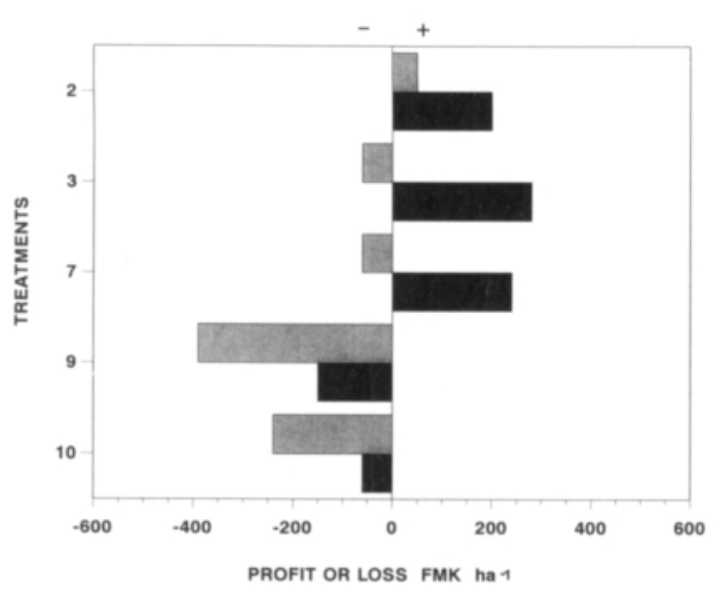

Fig. 7. Profitability of PGR treatments at different $\mathrm{N}$ levels in 1988-89. $\mathrm{N}_{1}$, comprises 22 trials, $\mathbf{N}_{2}, 22$ trials.

Treatments: 1 = untreated, $2=$ CCC time I, $3=$ CCC II, $7=$ mepiquat/ethephon II, 9 = ethephon III, 10 = mepiquat $/$ ethephon III.

Under the growth conditions represented by class 3 , which resulted in heavy lodging, the PGRs containing ethephon contributed to an economic return. In this class the volume weight of the yield generally remained low. Consequently, with the exception of the applications at flagleaf stage (FS 10), the quality of the yield was below the requirements for marketing, and the calculated profit (Fig. 6) on other treatments was not realistic. The profit achieved with different ethephon compounds at flag leaf stage varied from FIM 70 to 390 per ha.

In 1988-89, a small profit was achieved at the lower $\mathrm{N}$ level only with the earliest CCC treatment (FS 2) (Fig. 7). At the higher N level, PGR treatments to the 1-node stage (FS 6) of barley were profitable. Despite the better preventive effect on lodging, later use of ethephon and mepiquat/ethephon resulted in financial loss.

\section{Discussion}

\section{Lodging}

The results obtained with PGRs depended to a considerable extent on local growing conditions and in particular on the presence of lodging risk. This has been shown by several other workers, too (Woolley 1981, Caldwell et al. 1988, Herbert 1983, Simmons et al. 1988, Ma et al. 1992). In the absence of lodging the use of PGRs, ethephon compounds in particular, might even have an adverse effect on barley. Thus some Canadian results suggest that ethephon should only be used when there is a high risk of severe lodging (Moes 1990, Moes and Stobbe 1991).

Of plant growth regulating factors temperature and precipitation data are readily available to farmers. These were therefore chosen as factors which could be used to forecast the future lodging of barley and the need for PGR treatments.

The most important factors for future lodging turned out to be ETS over $+5^{\circ} \mathrm{C}$ and the PR between sowing date and the beginning of tillering (FS 2) of the crop. By influencing the growth intensity and development of the crop stand they affect its tendency to lodge. ETS corresponds to the mean temperature of the time interval measured (Lallukka et al. 1978) and thus the prevailing temperature level.

Weather conditions affecting lodging after the flag-leaf stage and the last treatment are not predictable. Heavy local showers from late July to harvesting are typical of Finnish conditions and cause uncertainty in prognose. This was seen in the explanatory levels of the equations, $64 \%$ for Arra and $68 \%$ for Kilta. In our study, the predicting future lodging by weather factors (Fig. 1) during early crop development matched well the reality in these limits (Table 3 ).

\section{Yield and yield components}

Early CCC application was not observed to increase tillering in this study, even at the higher nitrogen level used with success in some investigations (Höfner and Kühn 1982, Scheffer et al. 1983). On the other hand, the inefficacy of early CCC treatments has also been reported (Waddington and Cartwright 1986, Steen and Wünsche 1990). The lack of increased tillering in our 
Vol. 4: 429-443.

study might be attributed to the rapid development of plants under Finnish conditions. Owing to the long day, tillering lasts for about two weeks, which is probably too short for the crop plant to produce several tillers (Kivi 1967).

In general, no particular yield component was seen to clearly contribute to yield development. Consequently, the yield increase achieved with late applications of ethephon and mepiquat/ ethephon in group 3 may have been due to the prevention of lodge. Our results are supported by other studies in which the effect of PGRs on yield components varied between years and cultivars, hampering the identification of a single component as the major consistent factor (Ma and Smith 1991a, Ma et al. 1992).

The synergistic effect of PGR mixtures on the yield or yield components of barley reported in some studies (Karpenstein and Scheffer 1984, $\mathrm{Ma}$ and Smith 1991a) was not significant in our experiments (Fig. 4). This was in accordance with the investigations of Caldwell et al.(1988) who found that such results depended on the year and on the sensitivity of barley cultivars to PGRs.

\section{Profitability of using PGRs}

The profitability of growth regulator treatments depended on the amount, quality and price of the grain yield and the price of the PGR used. For example in classes 1 and 2, CCC treatment alone and, in class 2, CCC plus one tank mixture showed a slight profit due to their low costs (Fig. 6) since no significant yield differences existed between treatments. The same was noted in the trials at different $\mathrm{N}$ levels (Fig. 7). Under stressing growing conditions with heavy lodging all the treatments seemed to be more or less profitable. In reality, though, only three treatments, those with ethephon compounds and a mixture at flag- leaf stage, were profitable as the quality of the yield was poor with the other treatments.

Our study indicated that there is no financial gain to be obtained from using expensive PGRs in fodder barley unless the risk of lodging is really heavy. Profit was obtained with PGRs only when lodging was prevented or delayed. The same has been found in many previous studies (Woolley 1981, Herbert 1983, Simmons et al. 1988, Moes 1990). Ethephon treatments of fodder barley have given both profitable and unprofitable results in other experiments carried out by the experimental stations of the Agricultural Research Centre of Finland (Kangas 1993). The wide variation in the performance of PGRs is thus well recorded.

Acknowledgements. We thank the heads of the regional experimental stations of the Agricultural Research Centre, Ms. Sirkka-Liisa Hiivola, Mr. Aulis Järvi and Mr. Heikki Talvitie for participating in this study and for putting both their expertise and their facilities at our disposal.

\section{References}

Brückner, U. \& Höfner, W. 1980. Increased shortening and yield increase by combined application of the growth regulators $\mathrm{CCC}$ and ancymidol to spring wheat. Zeitschrift für Acker- und Pflanzenbau 149: 251-257.

Caldwell, C. B., Mellish, D. R. \& Norrie, J. 1988. A comparison of ethephon alone and in combination with CCC or DPC applied to spring barley. Canadian Journal of Plant Science 68: 941-946.

Höfner, W. \& Kühn, H. 1982. Effect of growth regulator combinations on ear development assimilate translocation and yield in cereal crops. Proceeding of Easter School in Agricultural Science 33: 375-390.
Herbert, C. D. 1983. Interactions between nitrogen fertilizers and growth retardants in practical cereal production. British Plant Growth Regulator Group, Monograph 1983, 9: 87-95.

Jung, J., Luib, M., Sauter, H., Zeeh, B. \& Rademacher, W. 1987. Growth regulation in crop plants with new types of triazole compounds. Journal of Agronomy and Crop Science 158: 324-332.

Kangas, A. 1993. Kokemuksia kasvunsăăteiden kăytöstă Etelă- Pohjanmaalla. Kasvinsuojeluseuran kasvinsuojelupäivăt 1993. p. 30-33.

Karpenstein, M. von \& Scheffer, K. 1984. Die ertrags- 
Erviö, L.-R. et al.: Benefit of using plant growth regulators in fodder barley

und wachstumsbeeinflussenden Wirkungen eines Wachstumsregulators auf der Basis von Mepiquatchlorid und etephon auf zwei Sommergerstensorten bei differenzierter N-Düngung. Landwirtschaftliche Forschung 37: 34.

Kivi, E. 1967. IImastotekijäin vaikutus mallasohrasadon mäărăăn ja laatuun. Mallasjuomat 1967: 295-317.

Köylijärvi, J. 1985. Ruiskutusten tallaustappiot viljakasvustoissa. Koetominta ja Kăytăntő 42: 32.

Lallukka, U., Rantanen, O. \& Mukula, J. 1978. The temperature sum requirements of barley varieties in Finland. Annales Agriculturae Fenniae 17: 185-191.

Large, E. C. 1954. Growth stages in cereals. Illustrations of the Feekes scale. Plant Pathology 3: 128-129.

Ma, B. \& Smith, D. 1991a. The effects of ethephon, chlormequat chloride and mixtures of ethephon and chlormequat chloride applied at the beginning of stem elongation on spike-bearing shoots and other yield components of spring barley (Hordeum vulgare L.). Journal of Agronomy and Crop Science 166: 127-135.

- \& Smith D. 1991b. Apical Development of spring barley in relation to chlormequat and ethephon. Agronomy Journal 83: 270- 274.

-, Leibovitch, S., Maloba, W. E. \& Smith, D. L. 1992. Spring barley responses to nitrogen fertilizer and ethephon in regions with short crop growing season. Journal of Agronomy and Crop Science 169: 151-160.

Moes, J. 1990. Assimilate partitioning, tillering and yield components in barley treated with ethephon. Dissertation Abstracts International B, Sciences and Engineering 51, 3: 1049- B.
- \& Stobbe, E. H. 1991. Barley treated with ethephon. I. Yield components and net grain yield. Agronomy Journal 83: 86-90.

Scheffer, K., Dippel, V., Hartung, E. G. \& Karpenstein, M. 1983. Der Einfluss eines Wachstumregulators auf Ertrag und Ertragskomponenten bei Sommergerste unter Ausschaltung von Lager. Zeitschrift für Acker- und Pflanzenbau 152: 284-292.

Simmons, S. R., Oelke, E. A., Wiersma, J. V., Lueschen, W. E. \& Warnes, D. D. 1988 . Spring wheat and barley responses to ethephon. Agronomy Journal 80: 829-834. Steen, E. \& Wünsche, U. 1990. Root growth dynamics of barley and wheat in field trials after CCC application. Swedish Journal of Agricultural Research 20: 57-62.

Työtehoseura 1992. Maatalouskoneiden vuokrasuositukset 1992. Työtehoseuran maataloustiedote 8/1992. $8 \mathrm{p}$.

Waddington, S. R. \& Cartwright, P. 1986. Modification of yield components and stem length in spring barley by the application of growth retardants prior to main shoot stem elongation. Journal of Agricultural Science 107: 367-375.

Woolley, E. W. 1981. Performance of Current growth regulators in cereals. British Plant Growth Regulator Group, Monograph 7: 44- 50.

Wünsche, U. 1977. Influence of growth retarding substances on cereals. 3. Field experiments with CCC, DPM and CEPA on wheat, rye, barley and oats. Zeitschrift für Acker- und Pflanzenbau 145: 238-253. 
Vol. 4: 429-443.

\title{
SELOSTUS
}

\section{Kasvunsääteiden käyttökelpoisuus ohralla}

\author{
Leila-Riitta Erviö, Heikki Jalli, Markku Kontturi, Heikki Hakkola, Arjo Kangas ja Paavo Simojoki \\ Maatalouden tutkimuskeskus
}

\begin{abstract}
Kasvunsääteiden vaikutusta ohran laon estämiseen ja sadonmuodostukseen erilaisissa kasvuoloissa tutkittiin vuosina 1985-89 kuudella koepaikalla Maatalouden tutkimuskeskuksessa. Tutkitut kasvunsääteet olivat klormekvatti ja etefoni yksinään sekä seoksina keskenään tai mepikvatin kanssa. Niillä käsiteltiin heikkokortiset Arra- ja Kilta-lajikkeet kolmena eri ajankohtana. Vuosina 1988-89 tutkimukseen sisältyi myös kaksi typpilannoitustasoa.

Viljan lakoontuminen vaihteli koekohtaisesti, eivätkä esiintyneet erot olleet yksiselitteisesti sidoksissa koepaikan maantieteelliseen sijaintiin tai tutkimusvuoteen.

Tutkimus osoitti, että kalliita kasvunsääteitä ei kannata käyttää rehuohrassa, ellei huomattavaa lakoriskiä ole olemassa. Lakoriskin muodostumiselle tärkeimpiä tekijöitä olivat tehoisa lämpötilasumma ja sademäärä ohran kylvön ja pensomisen alkuvaiheen (Feekes 2) välisenä aikana. Nämä tekijät selittivät $64 \%$ Arran ja $68 \%$ Killan lakoontumisesta. Niiden perusteella arvioitu lakoontuminen toteutui tässä tutkimuksessa ennusteen puitteissa.
\end{abstract}

Tutkituista kasvunsääteistä etefoni ja mepikvatti/etefoni lyhensivät kortta ja ehkäisivät lakoontumista tehokkaimmin, mutta eivät estäneet lakoa riittävästi epäedullisimmissa kasvuoloissa. Näiden valmisteiden käyttö ohran lippulehtiasteella lisäsi satoa ja voimakkaan lakoontumisen esiintyessä säilytti hehtolitrapainon kauppakelpoisuusrajan yläpuolella.

Ohran sadonmuodostusta sääteleviin tekijöihin kasvunsäädekäsittelyjen vaikutus jäi vähäiseksi. Varhainen klormekvattikäsittely ei lisännyt ohran versoutuvuutta.

Paikalliset kasvuolot ja laon esiintyminen osoittautuivat tärkeimmiksi tekijöiksi kasvunsäädekäsittelyjen kannattavuudelle. Ellei lakoa esiintynyt, käsittelyt eivät tuottaneet taloudellista hyötyä tai olivat suorastaan tappiollisia. Epäedullisissa kasvuoloissa, joissa lakoontuminen oli voimakasta, erityisesti etefonia sisältävät valmisteet auttoivat taloudellisen tuloksen saavuttamisessa. Niiden käyttö ohran lippulehtiasteella tuotti voittoa, joka vaihteli $70-390 \mathrm{mk} / \mathrm{ha}$ käsittelyjen mukaan. 